\title{
Cancer screening: the collateral damage of the pandemic in Egypt
}

\author{
Abdullah S. Eldaly@
}

To the Editor,

Severe acute respiratory syndrome coronavirus 2 (SARS-CoV-2) pandemic has cast a shadow on all cancer screening programs; millions of screening appointments were canceled due to the pandemic and resulting in depriving the population from a vital healthcare service that could save lives. One study in the USA reported a drastic drop in the screenings for breast, colon, and cervical cancer by $94 \%, 86 \%$, and $94 \%$ respectively between January 2020 and April 2020 [1]. In Japan, hepatocellular carcinoma (HCC) kept scheduled visits dropped dramatically from $97 \%$ before February 2020 to $49.1 \%$ in May 2020 according to one study [2]. The consequences of these canceled or postponed appointments will soon come to the surface and healthcare workers should be prepared for. In Egypt, the relatively weak screening programs for liver and breast cancer are expected to be the most severed as a direct result of understaffing, the fear of visiting the screening clinics, as well as turning many general hospitals and cancer institutes into SARS-CoV-2 isolation centers.

\section{HCC screening}

Hepatocellular carcinoma (HCC) is the fourth most common cause of cancer-related mortality in the world [1]. The most common cause of HCC is liver cirrhosis of any etiology.

Egypt has the second highest incidence rate of HCC in the world with an age-standardized rate (ASR) of 32.2 [3]. This heavy burden is a direct result of high $\mathrm{HCV}$ prevalence among Egyptians and is due to the government's parenteral anti-schistosomal therapy (PAT) masstreatment campaigns that took place between the 1950s and 1980s and lead to transmission of HCV throughout Egypt [4].

Correspondence: abdullaheldali@gmail.com

Department of Plastic and Reconstructive Surgery, Tanta University Hospitals, Tanta, Egypt

\section{Springer Open}

HCC is clinically silent in most patients until late stages and diagnosis could be challenging. Patients with tumors of a size of $2 \mathrm{~cm}$ or less could theoretically benefit from all treatment options while those with larger tumors or extra-hepatic spread have limited options and suffer worse prognosis. Screening for HCC in high-risk individuals was started in the 1980 s in order to early detect the tumor and possibly improve the outcomes [5]. The most recent screening guidelines recommend that all individuals at risk of $\mathrm{HCC}$ should undergo an alpha fetoprotein (AFP) test as well as abdominal ultrasonography at regular 6-month intervals.

The benefits of HCC surveillance programs were well established in 2004 when a randomized clinical trial conducted in China revealed that biannual screening using AFP and ultrasonography had reduced HCC mortality by $37 \%$ [6]. Moreover, the emergence of new effective treatments for early $\mathrm{HCC}$ in the last two decades has most likely increased the benefits from surveillance programs. HCC surveillance is now considered a cornerstone of the optimum care to cirrhotic patients and the vast majority of physicians would recommend screening for high-risk patients.

Although Egypt has a heavy burden of liver cirrhosis and $\mathrm{HCC}$, most of the government's attention is directed to $\mathrm{HCV}$ screening and eradication; a great success was achieved during the national campaign of HCV screening and eradication in 2018 and the country is moving steadily toward the elimination target [7]. However, cirrhotic patients remain at risk of developing $\mathrm{HCC}$ even after $\mathrm{HCV}$ eradication which means millions of Egyptians are still at risk of developing $\mathrm{HCC}$ despite the great success of the $\mathrm{HCV}$ eradication campaigns.

In Egypt, the weak HCC surveillance system is expected to be severed due to the pandemic. Over 300 public hospitals were turned into isolation centers for SARS-CoV-2 patients including many tropical medicine hospitals and some cancer and liver institutes [8]. The

(c) The Author(s). 2021 Open Access This article is licensed under a Creative Commons Attribution 4.0 International License, which permits use, sharing, adaptation, distribution and reproduction in any medium or format, as long as you give appropriate credit to the original author(s) and the source, provide a link to the Creative Commons licence, and indicate if changes were made. The images or other third party material in this article are included in the article's Creative Commons licence, unless indicated otherwise in a credit line to the material. If material is not included in the article's Creative Commons licence and your intended use is not permitted by statutory regulation or exceeds the permitted use, you will need to obtain permission directly from the copyright holder. To view a copy of this licence, visit http://creativecommons.org/licenses/by/4.0/. 
exact influence of the pandemic on the HCC surveillance program in Egypt is not exactly known because we lack enough data. However, it is not expected to differ significantly from the worldwide trend which means we are risking thousands of early $\mathrm{HCC}$ cases to pass unnoticed or be discovered when it is too late.

\section{Breast cancer screening}

With a staggering $200-400 \%$ increase in the relative incidence of breast cancer in Egypt between the years 1990 and 2017-an increase that was only surpassed by the Kingdom of Saudi Arabia-the deadly cancer has declared itself a challenging public health problem that needs urgent intervention [9]. This is, unfortunately, a part of the bigger picture where the burden of both cases and deaths is shifting steadily toward the less developed world as a direct result of urbanization and the resulting obesity and diabetes [10]. The survival depends greatly on the country's economic status: a study comparing cancer survival in five continents reported varying 5-year survival rates of $80 \%, 60 \%$, and $40 \%$ in high-income, middle-income, and low-income countries, respectively [11].

In Africa, the continent with the highest breast cancer mortality rates, the situation is becoming increasingly challenging [12]. The rapid industrialization without an equivalent growth in healthcare services and infrastructure has left African women with breast cancer more vulnerable than their peers in any other part in the world. The lack of screening, education, and campaigning lead to a great difference in staging at time of presentation between African and European women: about $50-70 \%$ of African women with breast cancer present with grade III or IV, while European women tend to present at stage I and II [13-15]. Ductal carcinoma is the most common histological type in Africa as well as the rest of the world. However, medullary and mucinous breast carcinomas are more reported in African women; these histological types tend to have poorer prognosis than ductal carcinoma. Moreover, the rates of the triple negative breast cancer (TNBC), which has the worst prognosis among other molecular subtypes, are significantly higher in African women [16]; this for sure adds to the aforementioned problem of late stages at presentation. Women with advanced stages are less likely to benefit from a breast conserving surgery leaving them to mastectomy, adjuvant hormonal therapy, chemotherapy, or even palliation. Women with TNBC are unfortunately less likely to respond to adjuvant hormonal therapy and chemotherapy which along with the late stages at presentation contributes to the suffering of African women with breast cancer [17].

Breast cancer is the most expensive cancer to treat [18]; this economic burden has important consequences on both the patients and the weak healthcare systems in the developing world. Breast cancer survivors, especially those who received adjuvant hormonal therapy suffer worsening financial status even with receiving financial assistance $[19,20]$. However, this financial burden could be greatly lowered through early detection since the cost of treatment is inversely related to the stage at presentation. A return-on-investment (ROI) analysis of a breast cancer screening program in Egypt found that the average perperson treatment cost for screened and unscreened patients was estimated to be $\$ 28,632$ and $\$ 58,170$, respectively, with a cumulative lifetime risk of $6.36 \%$. Total screening program cost per person was $\$ 112.10$. The study estimated an expected decrease in late-stage breast cancer diagnosis by $13.7 \%$ as a result of the screening program, saving $\$ 4049$ in treatment costs per individual diagnosed. The analysis resulted in a positive ROI of $133 \%$ for facility-based screening [21]. This is the economic rationale of the mass screening campaign for breast cancer that is currently running in Egypt.

Despite the initial success of the national campaign of breast cancer screening, the campaign was severed as the pandemic took over. Many hospitals that were participating in the campaign were turned into isolation centers for SARS-CoV-2 patients. Moreover, the understaffing that happened in other non-isolation hospitals affected the service in the outpatient clinics where women are supposed to be checked annually for breast cancer. Another important factor that markedly influenced breast cancer screening during the pandemic is the fear of getting infected with SARS-CoV-2 while doing the annual breast check in the hospital.

\section{What is next?}

There is no doubt Egypt needs to adopt new efficient strategies for cancer screening, but for now, we should aim to restore our pandemic-exhausted system first. The first step toward restoring the normal capacity of the healthcare system is to speed up the vaccination process. Unfortunately, Egypt has been performing poorly regarding the SARS-CoV-2 vaccination with only 164,534 doses administrated by April 2021 [22]. This weak performance will not only lead to more patients with SARS$\mathrm{CoV}-2$ exhausting the healthcare system but also will affect almost every chronic/high-risk patient including those who undergo regular cancer screening.

\footnotetext{
Abbreviations

SARS-CoV-2: Severe acute respiratory syndrome coronavirus 2; HCC: Hepatocellular carcinoma; HCV: Hepatitis C virus; HBV: Hepatitis B virus; DNA: Deoxyribonucleic acid; ASR: Age-standardized rate; PAT: Parenteral antischistosomal therapy; AFP: Alpha fetoprotein; TNBC: Triple negative breast cancer; ROI: Return-on-investment
} 


\section{Author's contributions}

The letter was solely written by the author. The author read and approved the final manuscript.

\section{Funding}

Not applicable.

\section{Availability of data and materials}

Not applicable.

\section{Declarations}

Ethics approval and consent to participate

Not applicable.

\section{Consent for publication}

Not applicable.

\section{Competing interests}

The author declares no competing interests.

Received: 30 March 2021 Accepted: 6 May 2021

Published online: 02 June 2021

\section{References}

1. Cancino RS, Su Z, Mesa R, Tomlinson GE, Wang J. The impact of COVID-19 on cancer screening: challenges and opportunities. JMIR Cancer. 2020:6. [cited 2021 Apr 13]. Available from: https://pubmed.ncbinlm.nih.gov/33027039/

2. Toyoda H, Yasuda S, Kiriyama S, Tanikawa M, Hisanaga Y, Kanamori A, et al. Impact of COVID-19 pandemic on surveillance of hepatocellular carcinoma: a study in patients with chronic hepatitis $C$ after sustained virologic response. GastroHep. 2020;2(5):247-52.

3. McGlynn KA, Petrick JL, London WT. Global epidemiology of hepatocellular carcinoma: an emphasis on demographic and regional variability. Clin Liver Dis. 2015;19:223-38.

4. Frank C, Mohamed MK, Strickland GT, Lavanchy D, Arthur RR, Magder LS, et al. The role of parenteral antischistosomal therapy in the spread of hepatitis C virus in Egypt. Lancet. 2000;355(9207):887-91.

5. Cottone M, Marceno MP, Maringhini A, Rinaldi F, Russo G, Sciarrino E, et al. Ultrasound in the diagnosis of hepatocellular carcinoma associated with cirrhosis. Radiology. 1983;147(2):517-9.

6. Zhang BH, Yang BH, Tang ZY. Randomized controlled trial of screening for hepatocellular carcinoma. J Cancer Res Clin Oncol. 2004;130(7):417-22.

7. Waked I, Esmat G, Elsharkawy A, El-Serafy M, Abdel-Razek W, Ghalab R, et al. Screening and treatment program to eliminate hepatitis $C$ in Egypt. N Engl J Med. 2020;382(12):1166-74.

8. Mersal: A lifeline for hospital beds in Egypt's virus fight - politics - Egypt Ahram Online. [cited 2021 Apr 13]. Available from: https://english.ahram.org. eg/NewsContent/1/64/373511/Egypt/Politics-/Mersal-A-lifeline-for-hospitalbeds-in-Egypt's-vir.aspx

9. Li N, Deng Y, Zhou L, Tian T, Yang S, Wu Y, et al. Global burden of breast cancer and attributable risk factors in 195 countries and territories, from 1990 to 2017: results from the Global Burden of Disease Study 2017. J Hematol Oncol. 2019;12(1).

10. Lukong KE, Ogunbolude Y, Kamdem JP. Breast cancer in Africa: prevalence, treatment options, herbal medicines, and socioeconomic determinants. Breast Cancer Research and Treatment, vol. 166. New York LLC: Springer; 2017. p. 351-65.

11. Coleman MP, Quaresma M, Berrino F, Lutz JM, De Angelis R, Capocaccia R, et al. Cancer survival in five continents: a worldwide population-based study (CONCORD). Lancet Oncol. 2008;9(8):730-56.

12. Ferlay J, Soerjomataram I, Dikshit R, Eser S, Mathers C, Rebelo M, et al. Cancer incidence and mortality worldwide: Sources, methods and major patterns in GLOBOCAN 2012. Int J Cancer. 2015;136(5):E359-86.

13. Rambau P, Chalya P, Manyama M, Jackson K. Pathological features of breast cancer seen in northwestern Tanzania: a nine years retrospective study. BMC Res Notes. 2011:4.

14. Boder JME, Abdalla FBE, Elfageih MA, Abusaa A, Buhmeida A, Collan Y. Breast cancer patients in Libya: comparison with European and central African patients. Oncol Lett. 2011;2(2):323-30.
15. OF I, Kronqvist P, Kuopio T, Ndoma-Egba R, Collan Y. Histopathology of breast cancer in different populations: comparative analysis for Finland and Africa. Electron J Pathol Histol. 2002;8(4):24011-8.

16. Eng A, McCormack V, dos-Santos-Silva I. Receptor-defined subtypes of breast cancer in indigenous populations in Africa: a systematic review and meta-analysis. Plos Med 2014;11(9).

17. Nagini S. Breast cancer: current molecular therapeutic targets and new players. Anticancer Agents Med Chem. 2017;17(2):152-63.

18. Diaby V, Tawk R, Sanogo V, Xiao H, Montero AJ. A review of systematic reviews of the cost-effectiveness of hormone therapy, chemotherapy, and targeted therapy for breast cancer. Breast Cancer Research and Treatment Springer New York LLC; $2015 ; 151: 27-40$.

19. Semin JN, Palm D, Smith LM, Ruttle S. Understanding breast cancer survivors' financial burden and distress after financial assistance. Support Care Cancer. 2020;28(9):4241-8.

20. Pezzin $L E, O^{\prime} N$ Niel MB, Nattinger $A B$. The economic consequences of breast cancer adjuvant hormonal treatments. J Gen Intern Med. 2009 24(SUPPL. 2).

21. Skrundevskiy AN, Omar OS, Kim J, Soliman AS, Korolchuk TA, Wilson FA. Return on investment analysis of breast cancer screening and downstaging in Egypt: implications for developing countries. Value Heal Reg Issues. 2018; 16:22-7.

22. Covid world vaccination tracker - The New York Times. [cited 2021 Apr 13]. Available from: https://www.nytimes.com/interactive/2021/world/covid-va ccinations-tracker.htm

\section{Publisher's Note}

Springer Nature remains neutral with regard to jurisdictional claims in published maps and institutional affiliations.

\section{Submit your manuscript to a SpringerOpen ${ }^{\circ}$ journal and benefit from:}

- Convenient online submission

- Rigorous peer review

- Open access: articles freely available online

High visibility within the field

- Retaining the copyright to your article

Submit your next manuscript at $\boldsymbol{\nabla}$ springeropen.com 